\title{
Silencing of ATP synthase $\beta$ induces female sterility in a leafhopper phytoplasma vector
}

\author{
Luciana Galetto, ${ }^{1, *}$ Matteo Ripamonti, ${ }^{1,2}$ Simona Abbà1, Marika Rossi1, \\ Marcello Manfredi3,4, Domenico Bosco ${ }^{1,2}$, and Cristina Marzachì1
}

1 Istituto per la Protezione Sostenibile delle Piante, Consiglio Nazionale delle Ricerche, IPSP-CNR, Strada delle Cacce 73 10135 Torino, Italy

2 Dipartimento di Scienze Agrarie, Forestali ed Alimentari DISAFA, Università degli Studi di Torino, Largo Paolo Braccini 2, 10095 Grugliasco (TO), Italy

3 Dipartimento di Medicina Traslazionale, Università del Piemonte Orientale, Palazzo Bellini, Via Solaroli 17, 28100 Novara, Italy

${ }^{4}$ Center for Translational Research on Autoimmune and Allergic Diseases, University of Piemonte Orientale, Corso Trieste 15/A, 28100 Novara, Italy

* Corresponding author: luciana.galetto@ ipsp.cnr.it

With 7 figures and 3 tables

\begin{abstract}
The leafhopper Euscelidius variegatus Kirschbaum (Hemiptera: Cicadellidae) is a natural vector of the 'Candidatus Phytoplasma asteris' and a laboratory vector of the phytoplasma associated with grapevine Flavescence dorée. Previous studies indicated that RNA interference (RNAi) by dsRNA injection efficiently works in E. variegatus and that silencing of ATP synthase $\beta$ increases mortality and impairs phytoplasma multiplication. Here, a nearly complete female sterility was observed when ATP synthase $\beta$ was silenced. The sterility was associated with the absence of mature eggs in the ovaries. On the contrary, male genitalia morphology and sperm motility were similar to those observed in E. variegatus control specimens, treated with dsRNAs targeting green fluorescent protein (dsGFP). An over-expression of hexamerin (amino acid storage protein) and cathepsin L (lysosome proteinase) was observed at transcript and protein level in dsATPinjected females in comparison with dsGFP-injected insects, in both whole body and dissected ovary samples. Conversely, the expression of other genes known to be involved in oocyte development, namely vitellogenin, perilipin and digestive cystein protein, was not altered in dsATP-injected E. variegatus insects in comparison with dsGFP ones. Possible roles of ATP synthase $\beta$, hexamerin and cathepsin $L$ in oocyte and egg development are discussed. Insecticide treatments against vectors are the main strategies to counteract phytoplasma diseases, with negative impact on environment and public health. RNAi is a promising sustainable approach against insect vectors and ATP synthase $\beta$ could be a valid target gene, as its silencing, besides increasing mortality and reducing phytoplasma multiplication, induces female sterility.
\end{abstract}

Keywords: Euscelidius variegatus, Hemiptera: Cicadellidae, RNA interference, hexamerin, cathepsin L, Flavescence dorée phytoplasma

\section{Introduction}

The leafhopper Euscelidius variegatus Kirschbaum (Cicadellidae: Deltocephalinae) is a palearctic, multivoltine and polyphagous species, widespread in Europe, North Africa and introduced in North America. This species is the laboratory vector of the Flavescence dorée phytoplasma (Caudwell et al. 1972) and a natural vector of other phytoplasmas (Weintraub \& Beanland 2006), among which the chrysanthemum yellows strain (CY) of the 'Candidatus Phytoplasma asteris' (Conti et al. 1988). Phytoplasmas are plant-patho- genic bacteria that cause severe symptoms in infected plants, leading to heavy economic losses of many crops worldwide (Tomkins et al. 2018). In particular, Flavescence dorée phytoplasma of grapevines is a quarantine pest in the EU, with a severe impact on European viticulture (EFSA Panel on Plant Health 2014; EFSA Panel on Plant Health et al. 2016).

Phytoplasmas are obligate parasites and display a dual life cycle, infecting phloem of the host plant as well as the insect vector body. Several lines of evidence indicate that interactions between phytoplasmas and vector host cells are tightly regulated and determine transmission 
ability (Arricau-Bouvery et al. 2018; Galetto et al. 2011; Malembic-Maher et al. 2020; Rashidi et al. 2015; Suzuki et al. 2006; Trivellone et al. 2019). In particular, previous studies demonstrated that ATP synthase $\beta$ subunit of $E$. variegatus is expressed in the mitochondria as well as on the plasma membrane and interacts in vitro with the antigenic membrane protein of CY phytoplasma (Galetto et al. 2011). This latter protein is required for pathogen transmission in vivo (Rashidi et al. 2015). Moreover, RNA interference (RNAi) has been successfully applied to silence ATP synthase $\beta$ gene of $E$. variegatus following abdominal microinjection of dsRNAs (Abbà et al. 2019) and a significant reduction of phytoplasma multiplication is observed when this gene was silenced (Galetto et al. 2021). ATP synthase $\beta$ is part of the F1-F0 ATP synthase complex, a large multisubunit mitochondrial enzyme that uses the proton gradient generated by the respiratory chain to synthesize ATP, whose general structure is highly conserved throughout evolution (Leyva et al. 2003). The ATP synthase complex was thought for a long time to be exclusively located in the inner membrane of mitochondria, but its presence on the outer face of plasma membranes of many cell lines and tissues of mammals (Taurino and Gnoni 2018) and arthropods (Fongsaran et al. 2014; Liang et al. 2015a; Lin et al. 2009) has been undoubtedly demonstrated. Interestingly, ATP synthase $\beta$ in this ectopic location is known to i) function as a viral receptor, mediating the entry of viral particles into host arthropod cells (Fongsaran et al. 2014; Liang et al., 2015b; Liang et al., 2010), ii) interact with the juvenile hormone binding protein and with some lipid transfer proteins in different insect species (Fruttero et al. 2017; Zalewska et al. 2009) and iii) be involved in mammals in a variety of biological processes, such as metabolism of high-density lipoproteins, endothelial cell proliferation and antitumor activity (Vantourout et al. 2010). The involvement of ectopic ATP synthase $\beta$ in lipid metabolism is very conserved across evolution; in arthropods, it seems particularly important during oocyte development (Fruttero et al. 2017; Zalewska et al. 2009). Indeed, insect mature eggs contain large amounts of proteins and lipids that can serve as a source of energy and are mostly taken up by receptor mediated-endocytosis. Vitellogenin and lipophorin are hemolymph lipoproteins well known for supplying lipids to the insect oocyte (Ziegler and Van Antwerpen, 2006). Hexamerins are other hemolymph high molecular mass proteins that function as storage proteins and may supply amino acids during egg formation (Hathaway et al. 2009; Martins et al. 2011). Among a wide set of different gene products, cathepsin L, perilipin and digestive cysteine protein have been identified as further key molecules involved in oocytes development in two mosquito species (Diptera: Culicidae) (Telang et al. 2013).

Insecticide control of vector populations is the main strategy to counteract phytoplasma outbreaks (Marcone 2014).
Taken into account the undesirable effects on the environment and public health, more targeted and sustainable pest management approaches are urgently needed to cope with these diseases. RNAi is an efficient molecular tool for studying gene function and it is emerging as a powerful and precise approach to develop new control strategies of insect pests (Christiaens et al. 2020; Zhu and Palli 2020; Zotti et al. 2018). Generally, silencing of target genes increases insect mortality (Taning et al. 2020) or, in the case of vectors, reduces transmission ability (Kanakala and Ghanim 2016). In previous works, we have shown that silencing of ATP synthase $\beta$ decreases insect survival rate (Abbà et al. 2019) and also impairs phytoplasma multiplication (Galetto et al. 2021). The present work aims at describing another effect of ATP synthase $\beta$ silencing, female sterility, and deciphering the biological mechanism that can explain it. Microscope observations of genitalia morphology from treated insects as well as expression analyses of different genes involved in oocyte development were performed at the transcript and cognate protein levels. A possible regulation pathway is discussed.

\section{Materials and methods}

\subsection{Insect rearing}

Euscelidius variegatus were originally collected in Piedmont (Italy) and continuously reared on oat, Avena sativa (L.), inside plastic and nylon cages in growth chambers at 20-25 ${ }^{\circ} \mathrm{C}$ with a L16:D8 photoperiod. To obtain coeval newly-emerged $E$. variegatus adults, two weeks before each experiment, $4^{\text {th }}$ and $5^{\text {th }}$ instar nymphs were caged on oats and then used for dsRNA injection once they were adults.

\subsection{Synthesis and delivery of dsRNAs}

The complete coding sequence of E. variegatus ATP synthase $\beta$ (target mRNA) used in this work is available in the Transcriptome Shotgun Assembly (TSA) Database (BioProject: PRJNA393620) at NCBI under the accession number GFTU01013594.1 (Galetto et al. 2018). The dsRNA molecules, targeting fragments of $E$. variegatus ATP synthase $\beta$ or green fluorescent protein (GFP) as negative control and hereinafter referred to as dsATP and dsGFP, were obtained with the MEGAscript RNAi Kit (Thermo Fisher Scientific) as previously described (Abbà et al. 2019). Newly emerged adults were anaesthetized with $\mathrm{CO}_{2}$ and microinjected between two abdominal segments under a stereomicroscope using a fine glass needle connected to a Cell Tram Oil microinjector (Eppendorf). Each insect was microinjected with $0.5 \mu \mathrm{L}$ of dsRNAs at the concentration of $160 \mathrm{ng}$ $\mu \mathrm{L}^{-1}$. Groups of injected insects were then caged on oat plants and monitored daily until the end of the experiments. Dead insects were removed periodically. 


\subsection{Progeny collection and genitalia observation}

Following dsRNA delivery, groups of injected insects were caged on oats for 15 days according to the gender combinations listed in Tab. 1 and, about 60 days after the injection (dpi), offspring was collected and counted. Mean ratio of offspring per parental female was calculated by dividing the total number of collected F1 specimens by the number of parental females. To evaluate the effect of gene silencing on egg development before deposition and on male fertility, ovaries and testes were collected from injected insects at $15 \mathrm{dpi}$. Insects were anaesthetized with $\mathrm{CO}_{2}$ and organs were dissected with forceps and needles using a stereomicroscope in a drop of phosphate-buffered saline (PBS), mounted on glass slides and observed under a DM750 (Leica) microscope equipped with a CoolLED pE300white Illumination System, and triple LED cube filter for LED module $365 / 470 / 590 \mathrm{~nm}$. Images were acquired with a Leica EC4 camera controlled through the LAS EZ software. Observation of live sperm to evaluate motility was carried out on a glass slide in PBS under bright-field light microscope. Testes were also stained with 4', 6-diamidino-2-phenylindole (DAPI) at a concentration of $1 \mu \mathrm{g} / \mathrm{ml}$ and observed with the $365 \mathrm{~nm}$ filter. For gene expression analysis in ovaries, dissected organs were rinsed in PBS and stored at $-80^{\circ} \mathrm{C}$ prior RNA and protein extraction.

\subsection{RNA extraction, cDNA synthesis and gene expression analysis}

Total RNAs were extracted from single $E$. variegatus adults (dissected head and body or whole insect) following dsRNA injection, as previously described (Abbà et al. 2019), with Direct-zol RNA Mini Prep kit (Zymo Research), following the manufacturer's protocol and including the optional DNAse treatment step. Total RNAs were extracted with the same procedure from dissected ovaries, each sample containing organs obtained from three female insects. Concentration, purity, and quality of extracted RNA samples were analysed in a Nanodrop ND-1000 spectrophotometer (Thermo Fisher Scientific).

Quantitative RT-PCR (qRT-PCR) was used to quantify the ability of the injected dsRNAs to knockdown target mRNA
(ATP synthase $\beta$ ) and to measure the effect on transcript level of hexamerin-like protein 2 (GFTU01000362.1), transferrin (GFTU01012775.1), vitellogenin (GFTU01015625.1), lipid storage droplets surface-binding protein 2 homologue to perilipin (GFTU01013841.1), cathepsin L (GFTU01004471.1) and digestive cysteine protein 1 (GFTU01011080.1). These sequences were retrieved from the TSA database GFTU01, BioProject: PRJNA393620 (Galetto et al. 2018). Thirty insects were analysed for each dsRNA-injected group. For each sample, cDNA was synthesized from total RNA $(1 \mu \mathrm{g})$ with random hexamers using a High Capacity cDNA reverse transcription kit (Applied Biosystems). The resulting cDNA was used as a template $(1 \mu \mathrm{l})$ for qPCR in a $10 \mu \mathrm{L}$ volume mix, containing $1 \times$ iTaq Universal Sybr Green Supermix (Bio-Rad) and $300 \mathrm{nM}$ of each primer. All the primer pairs used for qPCR are listed in Tab. 2. Samples were run in duplicate in a CFX Connect Real-Time PCR Detection System (Bio-Rad). Cycling conditions were: $95{ }^{\circ} \mathrm{C}$ for $3 \mathrm{~min}$, and 40 cycles at $95{ }^{\circ} \mathrm{C}$ for $15 \mathrm{~s}$ and $60^{\circ} \mathrm{C}$ for $30 \mathrm{~s}$ of annealing/ extension step. The specificity of the PCR products was verified by melting curve analysis for all samples. No-template controls were always included in each plate. Primers targeting glutathione S-transferase and elongation factor- $1 \alpha$ were used as internal controls to normalize the cDNA among samples (Galetto et al. 2018). Normalized expression levels of each target gene for each sample were calculated by CFXMaestro ${ }^{\text {TM }}$ Software (Bio-Rad). The expression stability of reference genes was acceptable in the multi-plate gene study.

\subsection{Mono-dimensional protein gels}

Single insects injected with dsRNAs targeting either GFP or ATP synthase $\beta$ (six samples for each treatment, three males and three females) and collected at 15 dpi were homogenized in $1.5 \mathrm{~mL}$ tube with micro-pestle in $100 \mu \mathrm{L}$ of $\mathrm{Rx}$ Buffer $(0.1 \%$ Triton X-100, $100 \mathrm{mM} \mathrm{KCl}, 3 \mathrm{mM} \mathrm{NaCl}, 3.5 \mathrm{mM}$ $\mathrm{MgCl}_{2}, 1.25 \mathrm{mM}$ EGTA, and $10 \mathrm{mM}$ Hepes, $\mathrm{pH}$ 7.3) (Suzuki et al. 2006), sonicated for 1 min at RT and centrifuged for $1 \mathrm{~min}$ at $13000 \mathrm{~g}$. The supernatant was recovered and an aliquot was quantified in a UV-vis spectrophotometer with Bradford reagent (Bio-Rad) along a standard scale based on

Table 1. Effects of ATP synthase $\beta$ silencing on Euscelidius variegatus progeny. Numbers of offspring of $E$. variegatus following injection of newly emerged F0 parent adults with dsRNAs targeting ATP synthase $\beta$ or Green Fluorescent Protein (GFP), used as control. Groups of injected F0 females and males listed in the same line were caged together for 15 days right after the dsRNA injection. Offspring insects (F1) were collected about 60 days post injection.

\begin{tabular}{|c|c|c|c|c|c|}
\hline \multirow{2}{*}{$\begin{array}{l}\text { dsRNA injected in } \\
\text { F0 females }\end{array}$} & \multirow{2}{*}{$\begin{array}{l}\text { dsRNA injected in } \\
\text { F0 males }\end{array}$} & \multicolumn{2}{|c|}{$\mathrm{N}^{\circ} \mathrm{F} 0$ parental insects } & \multirow{2}{*}{$\begin{array}{c}\text { Total } N^{\circ} \text { of offspring } \\
\text { (F1) }\end{array}$} & \multirow{2}{*}{$\begin{array}{c}\text { Mean ratio of } \\
\text { offspring/parental } \\
\text { female }\end{array}$} \\
\hline & & males & females & & \\
\hline GFP & GFP & 21 & 32 & 623 & 19.47 \\
\hline GFP & ATP synthase $\beta$ & 9 & 12 & 301 & 25.08 \\
\hline ATP synthase $\beta$ & GFP & 15 & 17 & 2 & 0.118 \\
\hline ATP synthase $\beta$ & ATP synthase $\beta$ & 17 & 37 & 7 & 0.189 \\
\hline
\end{tabular}


Table 2. List of primers used for gene expression analysis.

\begin{tabular}{|c|c|c|c|c|c|c|}
\hline Primer name & $5^{\prime}-3^{\prime}$ sequences & Target gene & $\begin{array}{l}\text { Product } \\
\text { size }\end{array}$ & $\begin{array}{c}\text { qPCR } \\
\text { efficiency }\end{array}$ & $\mathbf{R}^{2}$ & $\begin{array}{l}\text { Melt } \\
\text { peak }\end{array}$ \\
\hline АТР $\beta F w 622^{1}$ & CGCTTTACTCAGGCTGGTTC & \multirow{2}{*}{ ATP synthase $\beta$} & \multirow{2}{*}{$171 \mathrm{nt}$} & \multirow{2}{*}{$100 \%$} & \multirow{2}{*}{0.995} & \multirow{2}{*}{$84.5^{\circ} \mathrm{C}$} \\
\hline ATP $\beta R v 792^{1}$ & GTCATCAGCTGGCACGTAGA & & & & & \\
\hline HEX_F265 & CTGCCTCGTGGACAAGTGTG & \multirow{2}{*}{$\begin{array}{l}\text { hexamerin-like } \\
\text { protein } 2\end{array}$} & \multirow{2}{*}{$145 \mathrm{nt}$} & \multirow{2}{*}{$96.6 \%$} & \multirow{2}{*}{0.993} & \multirow{2}{*}{$82.5^{\circ} \mathrm{C}$} \\
\hline HEX_R409\# & TGCCCTCGTTCATGTTGTTG & & & & & \\
\hline TRF_F1370\# & CCGTGGTCAAGAAGTCCTCC & \multirow{2}{*}{ transferrin } & \multirow{2}{*}{$125 \mathrm{nt}$} & \multirow{2}{*}{$95.5 \%$} & \multirow{2}{*}{0.998} & \multirow{2}{*}{$84.5^{\circ} \mathrm{C}$} \\
\hline TRF_R1494\# & CCCCGACATTACGAGCTTGT & & & & & \\
\hline Vitel_F\# & ATCTACCAGAACACCGGAGA & \multirow{2}{*}{ vitellogenin } & \multirow{2}{*}{$113 \mathrm{nt}$} & \multirow{2}{*}{$105.1 \%$} & \multirow{2}{*}{0.994} & \multirow{2}{*}{$80.0^{\circ} \mathrm{C}$} \\
\hline Vitel_R $\#$ & TCGTTGGTGAACTGAGCCAT & & & & & \\
\hline Perilip_F\# & ATTCTGGAGAGCACCAAGGA & \multirow{2}{*}{ perilipin } & \multirow{2}{*}{$101 \mathrm{nt}$} & \multirow{2}{*}{$86.9 \%$} & \multirow{2}{*}{0.998} & \multirow{2}{*}{$83.0^{\circ} \mathrm{C}$} \\
\hline Perilip_R $\mathrm{R}^{\#}$ & TCCTTGAGAGAAGCCACGTT & & & & & \\
\hline CathL473_F² & CGTCAAGAAGCAGGGCCAAT & \multirow{2}{*}{ cathepsin L } & \multirow{2}{*}{$92 \mathrm{nt}$} & \multirow{2}{*}{$92.8 \%$} & \multirow{2}{*}{0.999} & \multirow{2}{*}{$82.0^{\circ} \mathrm{C}$} \\
\hline CathL473_R ${ }^{2}$ & CCAGCTTGCCAGACTTGAGG & & & & & \\
\hline EvaCProt72665_F" & TCACCCCTGTCAAAGATCAGT & \multirow{2}{*}{$\begin{array}{c}\text { digestive cysteine } \\
\text { protein }\end{array}$} & \multirow{2}{*}{$99 \mathrm{nt}$} & \multirow{2}{*}{$98.8 \%$} & \multirow{2}{*}{0.999} & \multirow{2}{*}{$81.0^{\circ} \mathrm{C}$} \\
\hline EvaCProt72665_R ${ }^{\#}$ & GCAGTTGCCCGGTCTTGACG & & & & & \\
\hline EF1- $\alpha \_F 215^{2}$ & CCATCGACATTGCCCTGTGG & \multirow{2}{*}{$\begin{array}{l}\text { elongation } \\
\text { factor-1 } \alpha\end{array}$} & & & & \\
\hline EF1- $\alpha \_R 325^{2}$ & CCTGTGAGGTTCCAGTGATCATG & & $111 \mathrm{nt}$ & $87.9 \%$ & 0.997 & $78.5^{\circ} \mathrm{C}$ \\
\hline GST1_F2572 & CCAAGGACCCCAAGAAGCGA & glutathione & & & & \\
\hline GST1_R3692 & TGGCGCTCCTCCAAACATCA & S-transferase & $113 \mathrm{nt}$ & $87.3 \%$ & 0.997 & $79.0^{\circ} \mathrm{C}$ \\
\hline
\end{tabular}

\# Primers designed in this work.

1 (Galetto et al. 2013).

2 (Galetto et al. 2018).

known dilutions of Bovine Serum Albumin (BSA) dissolved in Rx Buffer. Total proteins were extracted and quantified with the same procedures from dissected ovaries homogenized in $30 \mu \mathrm{L}$ of Rx Buffer, each sample containing organs obtained from two female insects, for a total of six females analysed for each treatment. For each sample, $1 \mu \mathrm{g}$ of total proteins was loaded onto $12 \%$ polyacrylamide gels (Fig. 2) or onto $4-20 \%$ polyacrylamide gels (Fig. 7 ), together with $3 \mu \mathrm{L}$ of Sharpmass VII Prestained Protein Marker (EuroClone). Gels were either stained with colloidal Coomassie stain (Candiano et al. 2004), to confirm that the amount of total proteins was equivalent among the different loaded samples, or blotted on polyvinylidene difluoride (PVDF) membranes for Western blots.

\subsection{Bi-dimensional protein gels}

A bi-dimensional protein separation was used to better discriminate and identify the unknown protein band that, according to 1D SDS-PAGE gels, resulted over-expressed in female insects injected with dsRNA targeting ATP synthase $\beta$. For 2D gels, total proteins were extracted from batches of three female insects injected with dsRNAs targeting either GFP or ATP synthase $\beta$ and collected at $15 \mathrm{dpi}$, to obtain highly concentrated samples as required by $2 \mathrm{D}$ procedure. Insect total proteins were extracted as previously detailed
(Ripamonti 2019). Isoelectrofocusing, equilibration and $2^{\text {nd }}$ dimension run were conducted as previously described (Margaria and Palmano 2011). The resulting 2-DE gels were stained with colloidal Coomassie (Candiano et al. 2004), and the 2-D gel image elaboration and analysis were carried out with the PDQuest software version 8.0.1 (Bio-Rad), according to the manufacturer's instructions.

\subsection{MS/MS identification}

The selected protein bands and spots were excised from 1D SDS-PAGE and 2D gels, respectively, for trypsin digestion and liquid chromatography-mass spectrometry (LC-MS) analysis with a Triple TOF 5600+ (Sciex, Concorde, Canada), according to methods previously described (Albanese et al. 2017). Protein identification was accomplished using the MASCOT database search engine against a local E. variegatus protein database obtained from TransDecoder-predicted coding regions of TSA transcripts (TransDecoder v5.5.0, https://github.com/TransDecoder/TransDecoder/).

\subsection{Western blots}

Total proteins from female whole bodies or ovaries, separated on mono-dimensional protein gels, were blotted on PVDF membranes with Trans-Blot Turbo Transfer System (BioRad). Membranes were blocked for 30 min with 3\% BSA 

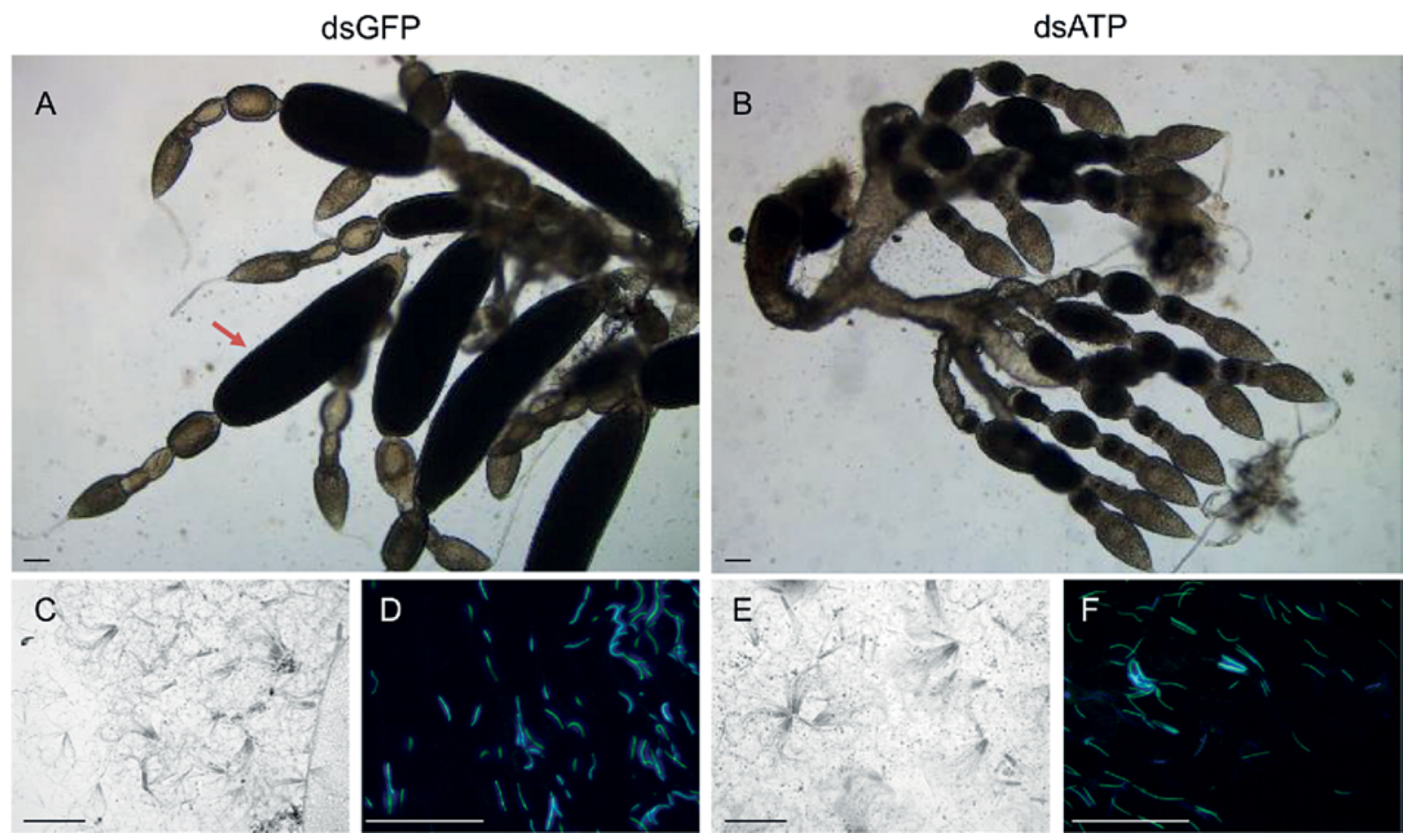

Fig. 1. Effects on Euscelidius variegatus genitalia following silencing of ATP synthase $\boldsymbol{\beta}$. Images of ovaries (panels $A, B$ ) and spermatozoa (panels $C$ to $F$ ) of $E$. variegatus adults collected at 15 days post injection with dsRNAs (80 ng/ insect) targeting Green Fluorescent Protein, GFP, (panels A, C, D), used as control, or ATP synthase $\beta$ (panels B, E, F), observed in bright field (panels $A, B, C, E$ ) and with UV excitation at $405 \mathrm{~nm}$ after DAPI staining (panels D, F). Red arrow indicates a mature egg. Bars $=100 \mu \mathrm{m}$.

dissolved in Tris-buffered saline with $0.1 \%$ Tween (BSATBST) and incubated $4 \mathrm{~h}$ at RT with the primary antibodies anti-ATP synthase $\beta$ (AS05 085 rabbit-developed, Agrisera), anti-cathepsin L (ab200738 rabbit-developed, Abcam plc) and anti-actin (A5060 rabbit-developed, Sigma-Aldrich), diluted 1:10000, 1:1000 and 1:5000 in BSA-TBST, respectively. Blots were then washed four times with BSA-TBST, incubated for $2 \mathrm{~h}$ with horseradish peroxidase-conjugated secondary antibody (A0545 anti-rabbit goat-developed, Sigma-Aldrich) diluted 1:15000 in BSA-TBST, washed four times with TBST, and developed with West Pico SuperSignal chemiluminescent substrate (Pierce) in a VersaDoc 4000 MP system (Bio-Rad).

\subsection{Statistical analyses}

SigmaPlot version 13 (Systat Software, Inc., www.systatsoftware.com.) was used for statistical analyses. As raw transcript data were not always normally distributed, they were natural log-transformed before analysis. ANOVA, followed by Holm-Sidak method as multiple comparison procedure, was used to compare transcript levels measured in whole body or separated head/body samples. T test or MannWhitney test, when the parametric analysis assumptions were not met, were used to compare transcript levels measured in dissected ovary samples.

\section{Results}

\subsection{ATP synthase $\beta$-silenced females lack progeny and show altered ovary morphology}

The number of offspring collected from different groups of parental insects, injected with dsRNAs targeting either GFP or ATP synthase $\beta$ is shown in Tab. 1. The levels of specific ATP synthase $\beta$ transcripts in parental insects were significantly reduced in dsATP groups in comparison with those measured in dsGFP samples (supplementary materials, Table $\mathrm{S} 1$ ). When ATP synthase $\beta$ was silenced in parental females, the collected progeny constantly consisted of very few specimens, irrespective of treatment of males allowed to mate with test females. An average 100-fold progeny reduction was observed in comparison with offspring collected from dsGFP-injected parental females.

To investigate whether the absence of progeny was due to anomalies before egg deposition, ovaries and testes from dsRNA injected insects were dissected and observed (Fig. 1). The absence of mature eggs was systematically observed in ovaries dissected from all dsATP-injected females analysed $(\mathrm{N}=30)$, whereas no evident alterations in testis morphology were observed in dsATP-injected males $(\mathrm{N}=15)$ in comparison with dsGFP-injected control insects (Fig. 1). Sperm motility was apparently similar in insects from the two 

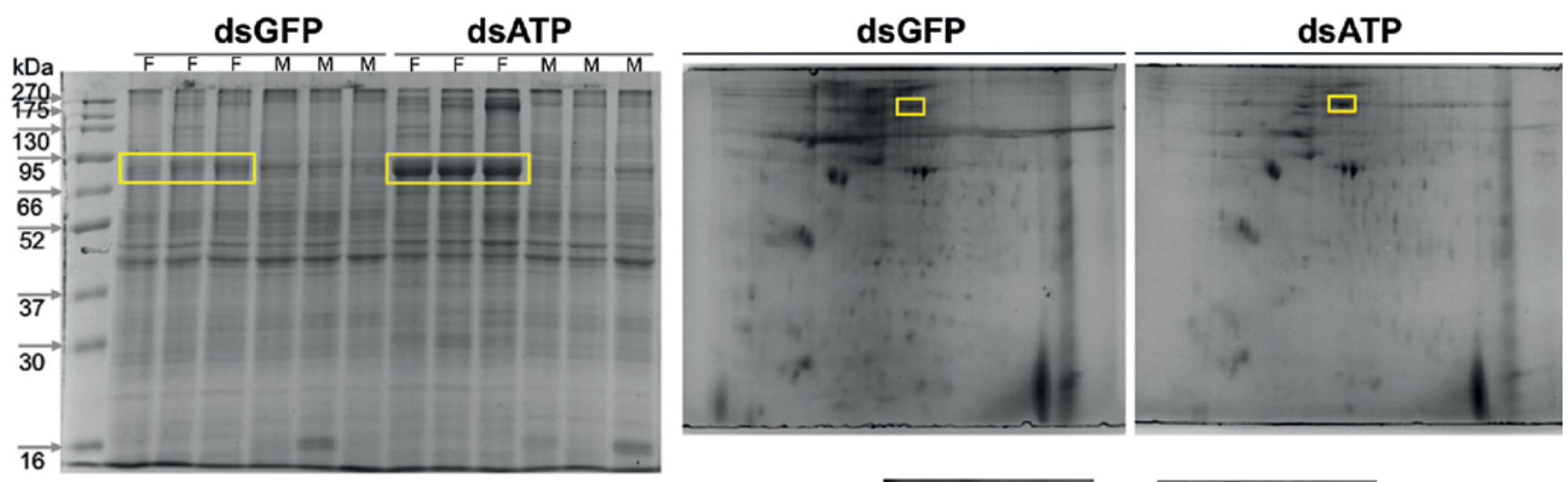

A
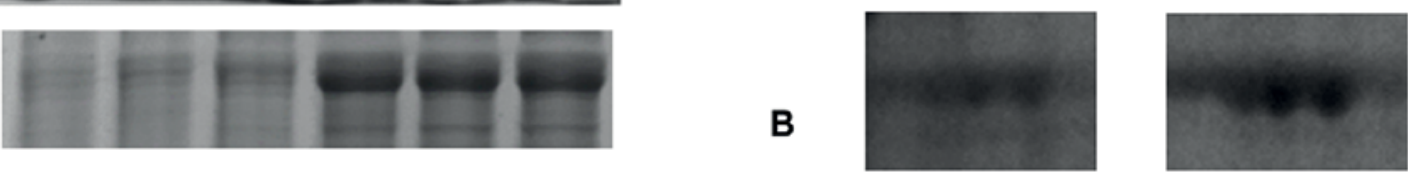

Fig. 2. Protein profiles of Euscelidius variegatus injected with dsRNAs. (A) Mono-dimensional SDS-PAGE of total proteins from female $(F)$ and male $(M)$ adults of $E$. variegatus collected at 15 days post injection with dsRNAs (80 ng/insect) targeting ATP synthase $\beta$ (dsATP) or Green Fluorescent Protein (dsGFP), used as control. (B) Bi-dimensional SDS-PAGE following isoelectrofocusing on 3-10 $\mathrm{pH}$ strips of total proteins from female adults of $E$. variegatus collected 15 days after the injection with dsATP or dsGFP. Yellow boxes in upper panels are magnified in corresponding lower panels and indicate the gel samples analysed in mass spectrometry (see Tab. 3).

treated groups (dsATP vs. dsGFP) (supplementary materials, videos).

\subsection{Hexamerin is over-expressed in ATP synthase $\beta$ silenced-females}

Together with lack of progeny and altered ovary morphology, strong over-expression of an unknown protein of about $90 \mathrm{kDa}$ (Fig. 2) was observed in dsATP-injected females at $15 \mathrm{dpi}$, when compared with dsATP-injected males and with coeval females injected with dsGFP. The over-expression of this unknown protein in dsATP-injected females was constantly observed in three independent experiments. The overexpressed bands and spots were excised from mono- and bi-dimensional protein gels (Fig. 2) and subjected to MS/ MS for protein identification following trypsin digestion. As background control, the same analysis was also performed on protein bands of dsGFP-injected females, co-migrating on the same mono-dimensional gel together with the overexpressed protein of dsATP-injected females (Fig. 2A, Tab. 3). Among the identified proteins from samples of the different silencing treatments, transferrin (mass: $75.3 \mathrm{kDa}$ ) and hexamerin-like protein 2 (mass: $84.4 \mathrm{kDa}$ ) were overexpressed in ATP synthase $\beta$ silenced-female insects in comparison with dsGFP-injected controls. Features of MS/MS analysis are detailed in Tab. 3. Mass spectrometry analysis indicated that hexamerin was present in all samples from dsATP-injected insects whereas absent in two out of three samples from dsGFP-injected insects (dsGFP1_gel1D and dsGFP2_gel1D). Moreover, in dsGFP3_gel1D sample the protein abundance index of hexamerin was six-fold less than the mean value measured in corresponding dsATP_gel1D samples.

To confirm the over-expression of transferrin and hexamerin-like protein 2, levels of the corresponding transcripts were measured at $15 \mathrm{dpi}$ in whole body of female and male insects injected with dsATP or dsGFP (Fig. 3). Expression of transferrin gene was not influenced by dsATP injection, whereas the abundance of hexamerin transcript was significantly higher in dsATP-injected females than in dsATPinjected males and dsGFP-injected insects (Fig. 3; ANOVA $\mathrm{F}=9.364, \mathrm{P}<0.001)$. A significant over-expression of hexamerin transcript was also observed in separated head and thorax-abdomen of dsATP-injected females in comparison with corresponding samples from dsGFP treated insects (Fig. 4; ANOVA $\mathrm{F}=44.457, \mathrm{P}<0.001$ ). As expected, ATP synthase $\beta$ was strongly silenced in treated insects irrespective of the gender (Fig. 3: ANOVA F $=279.784, \mathrm{P}<0.001$; Fig. 4: ANOVA $\mathrm{F}=144.642, \mathrm{P}<0.001)$.

\subsection{Hexamerin and cathepsin $L$ are over- expressed in ovaries of ATP synthase $\beta$ silenced-females}

A possible role of hexamerin in egg development was then hypothesized, and its expression was quantified in dissected ovaries, together with other genes specifically identified in ovaries that are likely involved in the nutrient mobilization, ovarian ecdysteroid production and regulation of these processes during oocyte maturation (Telang et al. 2013). In particular, a preliminary screening on the expression of vitellogenin, cathepsin L, perilipin and digestive cystein protein 
ATP synthase $\beta$
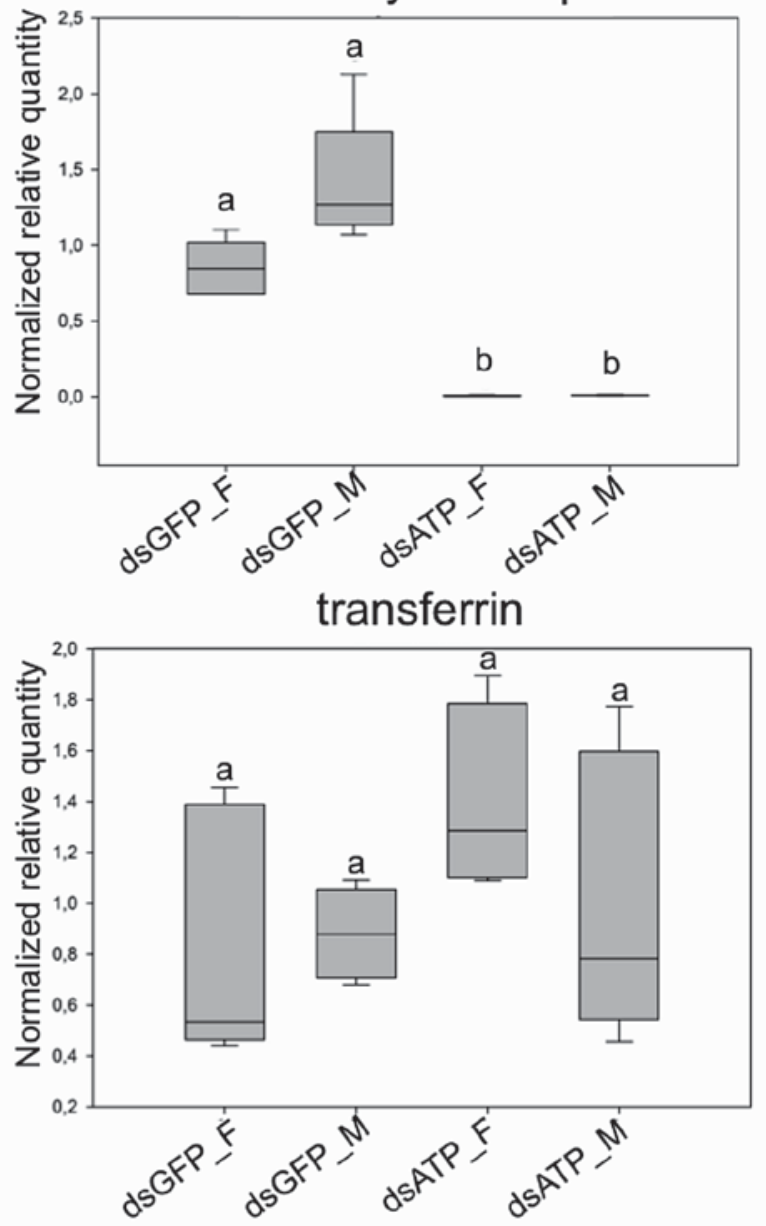

hexamerin

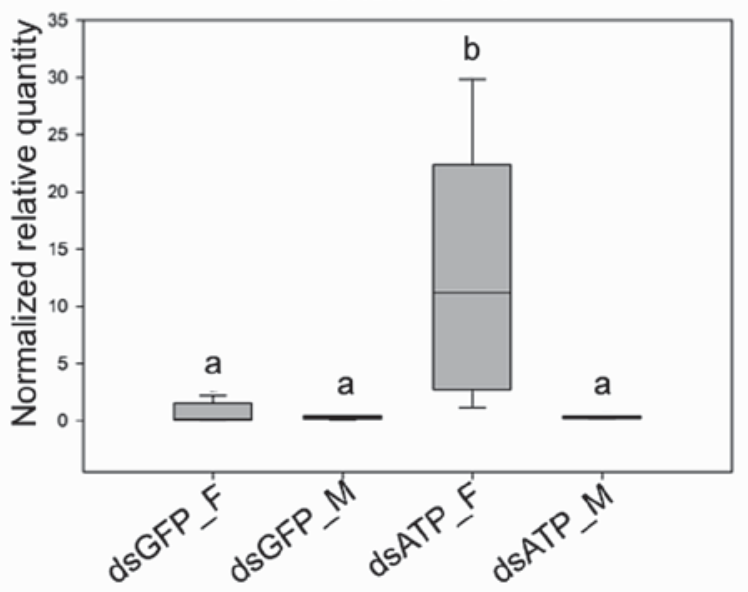

Fig. 3. Expression of ATP synthase $\beta$, transferrin and hexamerin. Transcript levels of the three genes measured in whole bodies of female $(F)$ and male $(M)$ adults of Euscelidius variegatus collected at 15 days post injection with dsRNAs ( $80 \mathrm{ng} / \mathrm{insect}$ ) targeting ATP synthase $\beta$ (dsATP) or Green Fluorescent Protein (dsGFP), used as control. Different letters indicate significant differences in transcript levels measured in diverse groups of samples (ANOVA, followed by Holm-Sidak method). The median of five samples is shown as a line across each box, the box indicates the $25^{\text {th }}$ and $75^{\text {th }}$ percentiles and whiskers represent the $90^{\text {th }}$ and $10^{\text {th }}$ percentiles.
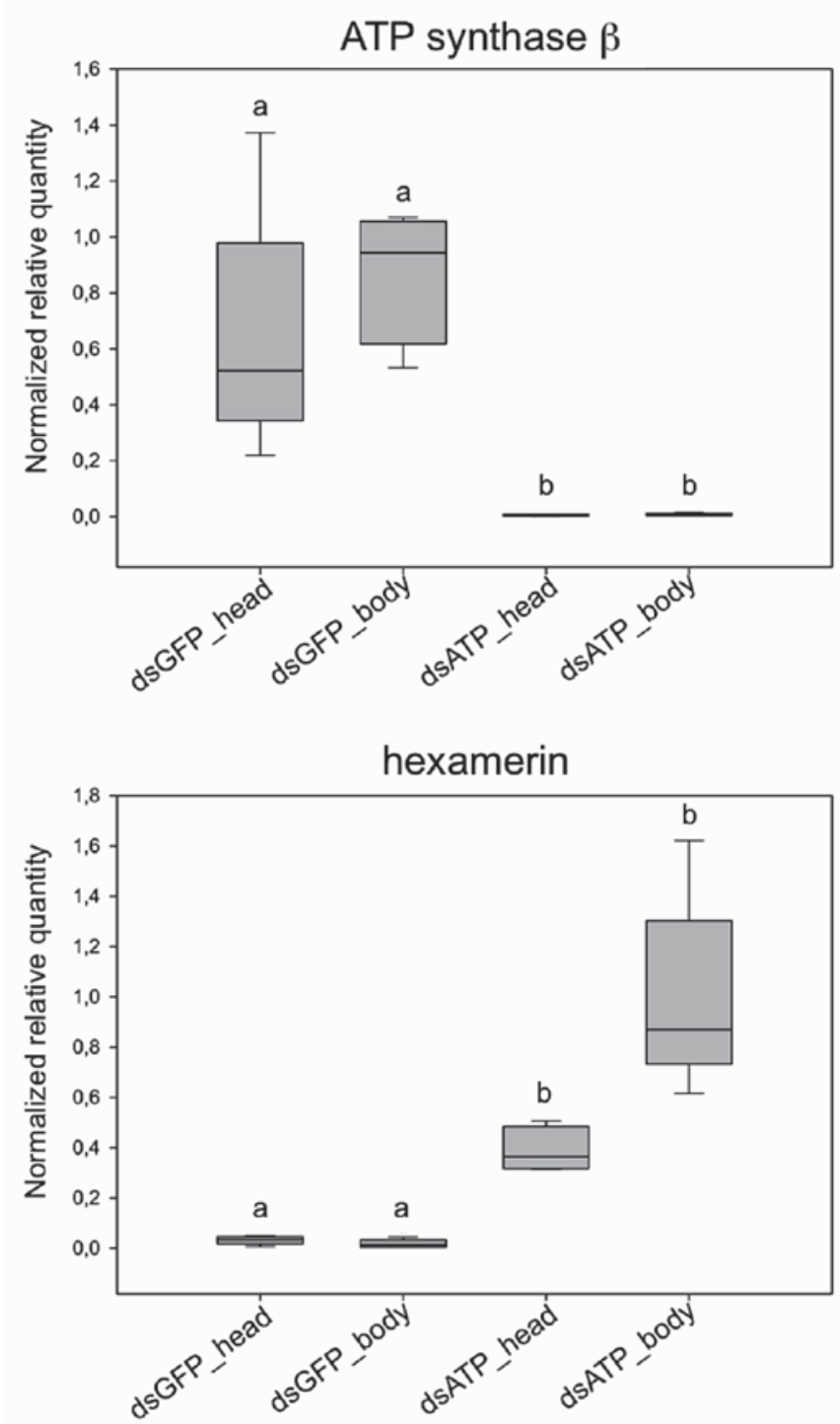

Fig. 4. Expression of ATP synthase $\beta$ and hexamerin in separated heads and bodies. Transcript levels of the two genes measured in separated heads and bodies of Euscelidius variegatus female adults collected at 15 days post injection with dsRNAs (80 ng/insect) targeting ATP synthase $\beta$ (dsATP) or Green Fluorescent Protein (dsGFP), used as control. Different letters indicate significant differences in transcript levels measured in diverse groups of samples (ANOVA, followed by Holm-Sidak method). The median of five samples is shown as a line across each box, the box indicates the $25^{\text {th }}$ and $75^{\text {th }}$ percentiles and whiskers represent the $90^{\text {th }}$ and $10^{\text {th }}$ percentiles. 
Table 3. Protein identification. Features of MS/MS analysis of transferrin and hexamerin-like protein 2 identified from different samples of Euscelidius variegatus injected with dsRNAs targeting ATP synthase $\beta$ (dsATP) or Green Fluorescent Protein (dsGFP) obtained from mono-dimensional (gel1D) and bi-dimensional (gel2D) electrophoresis (see yellow boxes of Fig. 2).

\begin{tabular}{|c|c|c|c|c|c|c|}
\hline \multirow{2}{*}{ Sample-ID } & \multicolumn{2}{|c|}{ MASCOT score } & \multicolumn{2}{|c|}{$\mathrm{N}^{\circ}$ of peptides } & \multicolumn{2}{|c|}{ emPAI* } \\
\hline & transferrin & hexamerin & transferrin & hexamerin & transferrin & hexamerin \\
\hline dsATP1_gel1D & 3011 & 2876 & 42 & 35 & 8.01 & 3.1 \\
\hline dsATP2_gel1D & 3022 & 2292 & 50 & 34 & 8.01 & 3.31 \\
\hline dsATP3_gel1D & 3547 & 2220 & 54 & 32 & 12.35 & 2.9 \\
\hline dsATP4_gel2D & 3825 & 133 & 46 & 5 & 7.04 & 0.22 \\
\hline dsGFP1_gel1D & 564 & 1 & 14 & l & 0.86 & l \\
\hline dsGFP2_gel1D & 662 & l & 15 & / & 1.19 & l \\
\hline dsGFP3_gel1D & 2304 & 275 & 36 & 8 & 4.74 & 0.5 \\
\hline
\end{tabular}

*emPAI: exponentially modified Protein Abundance Index

/ indicates absence of the protein in the analysed sample.
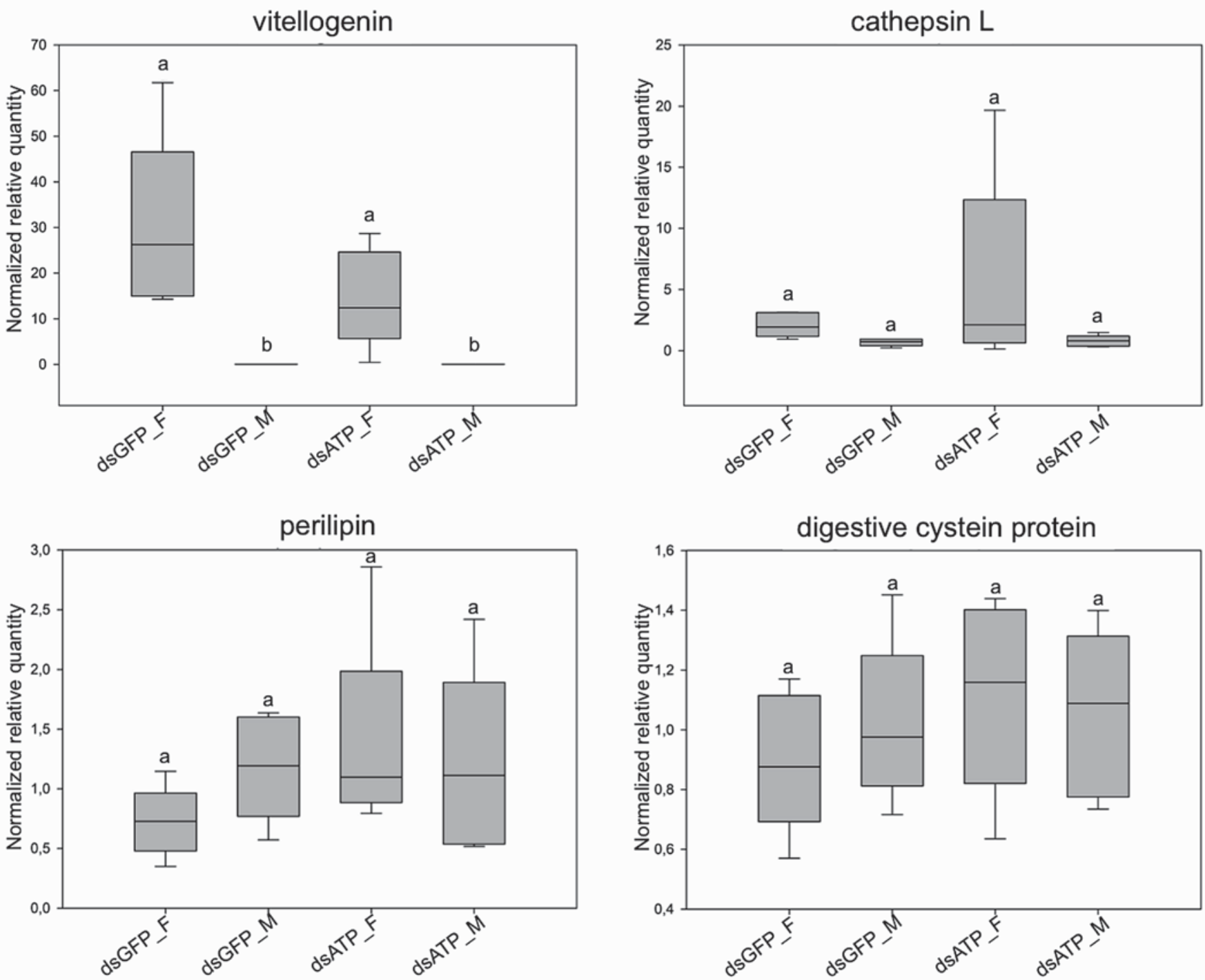

Fig. 5. Transcript level of four genes putatively involved in egg development. Transcript level of vitellogenin, perilipin, cathepsin $\mathrm{L}$ and digestive cysteine protein genes measured in whole bodies of female (F) and male (M) adults of Euscelidius variegatus collected at 15 days post injection with dsRNAs ( $80 \mathrm{ng} / \mathrm{insect}$ ) targeting ATP synthase $\beta$ (dsATP) or Green Fluorescent Protein (dsGFP), used as control. Different letters indicate significant differences in transcript levels measured in diverse groups of samples (ANOVA, followed by Holm-Sidak method). The median of five samples is shown as a line across each box, the box indicates the $25^{\text {th }}$ and $75^{\text {th }}$ percentiles and whiskers represent the $90^{\text {th }}$ and $10^{\text {th }}$ percentiles. 


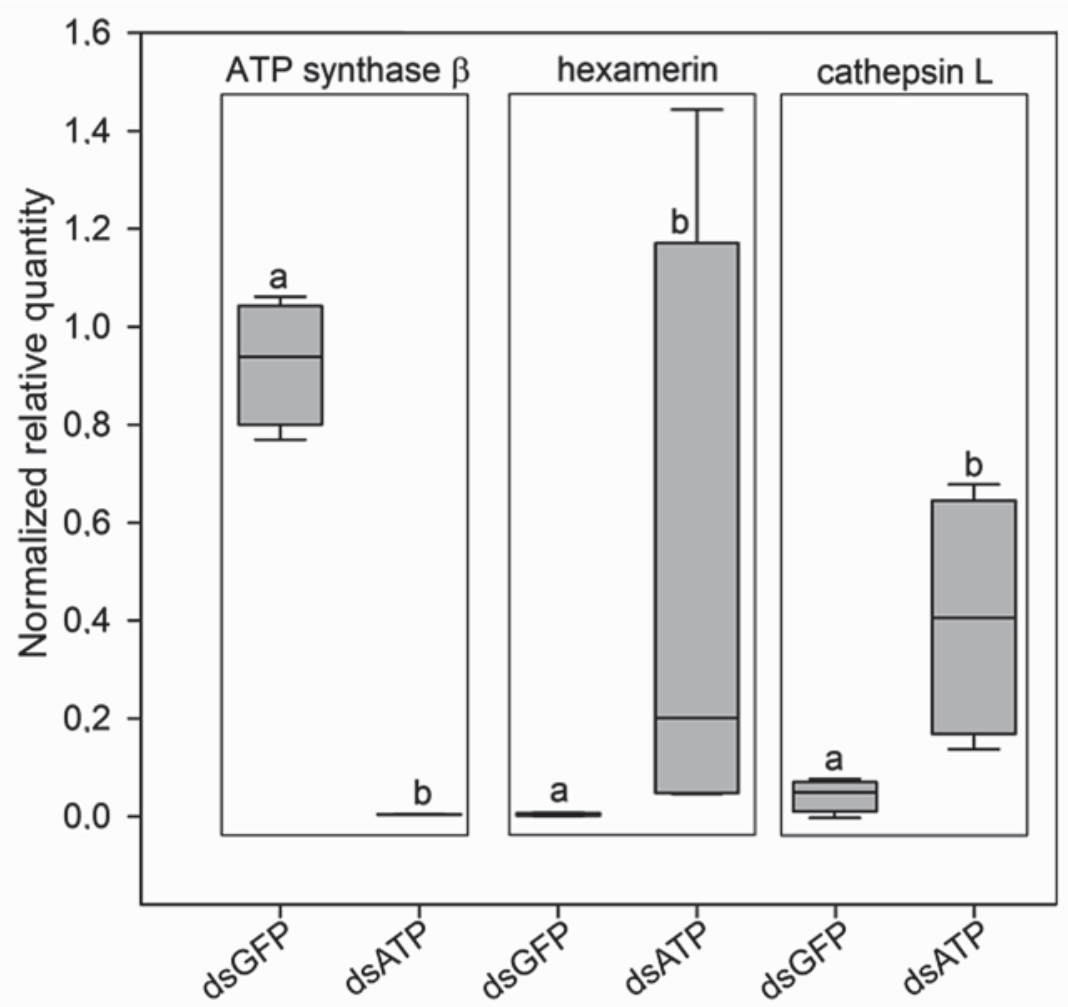

Fig. 6. Transcript level of ATP synthase $\beta$, hexamerin and cathepsin $L$ genes in ovaries. Transcript level of listed genes measured in dissected ovaries of female adults of Euscelidius variegatus collected at 15 days post injection with dsRNAs (80 ng/insect) targeting ATP synthase $\beta$ (dsATP) or Green Fluorescent Protein (dsGFP), used as control. Different letters indicate significant differences in transcript levels measured in the two groups of samples within each box ( $t$ test for ATP synthase $\beta$ and hexamerin, Mann-Whitney for cathepsin L). The median of four samples is shown as a line across each box, the box indicates the $25^{\text {th }}$ and $75^{\text {th }}$ percentiles and whiskers represent the $90^{\text {th }}$ and $10^{\text {th }}$ percentiles. Each sample contains organs obtained from three female insects.

genes was performed on whole bodies of dsGFP- vs. dsATPinjected insects (Fig. 5). The expression of the four genes was not significantly altered in silenced insects, even if vitellogenin showed a trend of down-regulation and cathepsin L a trend of up-regulation, in silenced females in comparison with dsGFP-injected females (Fig. 5). Several isoforms of cathepsin L are expressed in E. variegatus and the isoform 473 , analysed here, is more transcribed in females than in males (Galetto et al. 2018).

The expression analysis in dissected ovaries from dsATPand dsGFP-injected females at 15 dpi confirmed a strong silencing of the target ATP synthase $\beta$ gene, as expected, together with significant up-regulation of hexamerin and cathepsin L in silenced females (Fig. 6; ATP synthase $\beta$ : $\mathrm{t}$ test, $\mathrm{t}=-46.508, \mathrm{P}<0.001$; hexamerin: $\mathrm{t}$ test, $\mathrm{t}=4.283$, $\mathrm{P}=0.003$; cathepsin L: Mann-Whitney $\mathrm{T}=26.000, \mathrm{P}=$ $0.029)$. The expression of vitellogenin transcript was not significantly altered in ovary samples of silenced insects (supplementary materials, Table S2).
At protein level, different electrophoretic patterns were observed in whole bodies (Fig. 7A) and ovaries (Fig. 7B) of silenced female insects in comparison with GFP treated samples. In particular, the yellow box indicates an overexpressed band at about $90 \mathrm{kDa}$ (presumably hexamerin) in whole bodies of dsATP-injected samples and the blue box points to an over-expressed band at about $200 \mathrm{kDa}$ in dsGFP ovary samples. The expression of ATP synthase $\beta$ protein was down-regulated in both whole bodies (Fig. 7A) and ovaries (Fig. 7B) of silenced female insects in comparison with GFP treated samples, as expected. An over-expression of cathepsin L together with a different pattern of premature/mature forms were observed in ovaries from dsATPinjected insects in comparison with dsGFP-injected controls (Fig. 7B), as in two out of three dsATP ovary samples the premature form was abundant while it was absent in all three dsGFP ovary samples. On the other hand, in whole female bodies (Fig. 7A) cathepsin L protein amount was similar in dsATP and dsGFP samples. Abundance of actin protein, 


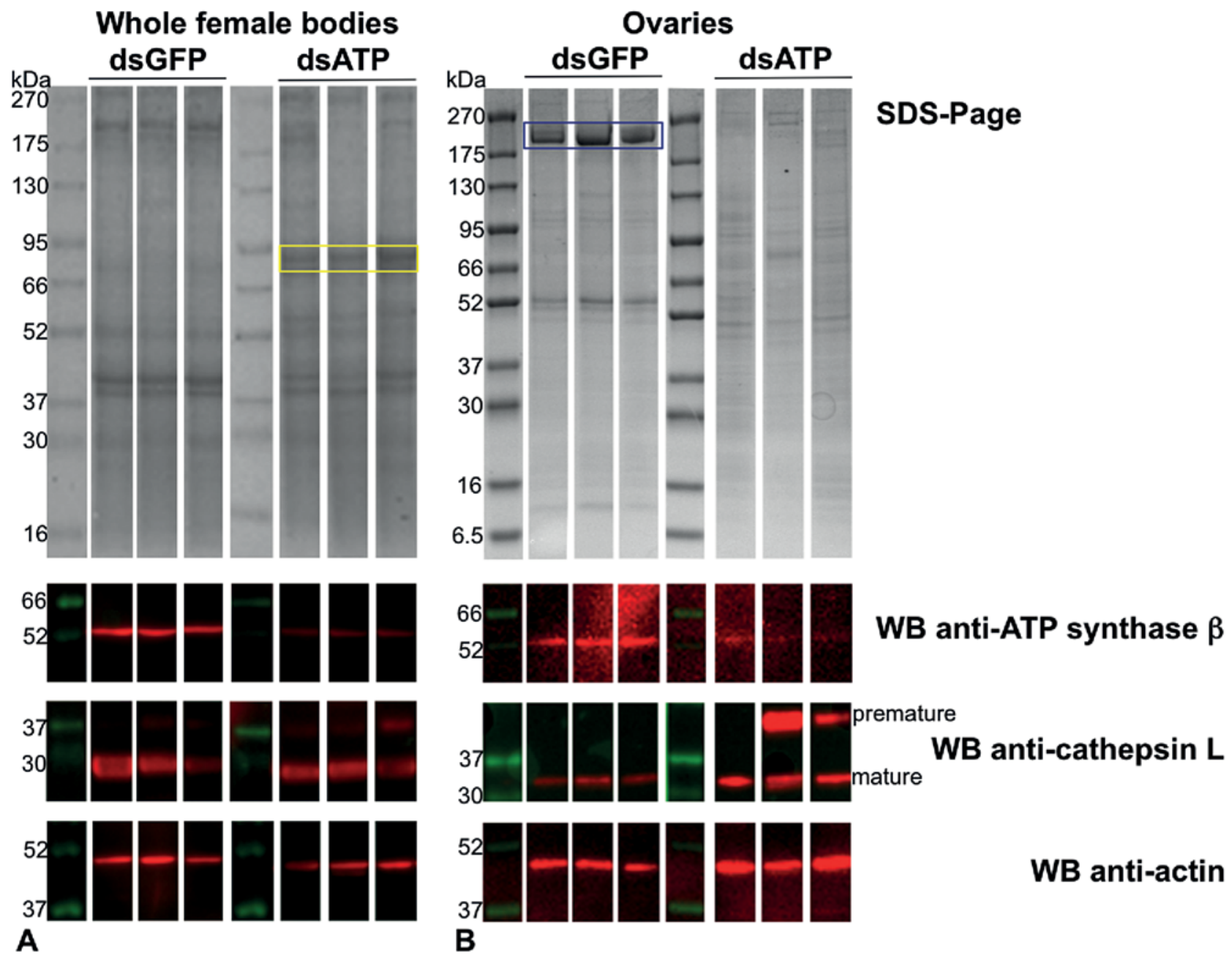

Fig. 7. Level of ATP synthase $\beta$ and cathepsin L proteins in whole female bodies and ovaries. Mono-dimensional SDS-PAGE and corresponding Western blots developed with different primary antibodies (anti-ATP synthase $\beta$, anti-cathepsin L and anti-actin) of total proteins from whole female bodies (A) and ovaries (B) of Euscelidius variegatus collected at 15 days post injection with dsRNAs (80 ng/insect) targeting ATP synthase $\beta$ (dsATP) or Green Fluorescent Protein (dsGFP), used as control. Yellow and blue boxes indicate over-expressed protein bands in dsATP whole body $(\sim 90 \mathrm{kDa})$ and dsGFP ovary samples ( 200 kDa), respectively. In Western blot panels, signals of specific antibodies and molecular weights of Sharpmass VII Prestained Protein Marker (EuroClone) are indicated in green and red respectively. Actin was used as housekeeping protein among different samples.

checked as housekeeping, was comparable among different samples (Fig. 7A and B).

\section{Discussion}

This work demonstrated that, upon silencing of the ATP synthase $\beta$ gene, the reproduction of the phytoplasma vector E. variegatus is impaired due to inability to develop eggs. At the molecular level, this phenotype is characterized by enhanced transcription of the hexamerin-like protein 2 and cathepsin L genes in E. variegatus females, especially in the ovaries. Silenced females showed also high level of hexamerin protein and Western blot of total ovary proteins con- firmed overexpression of the cathepsin L protein together with low levels of ATP synthase $\beta$ gene product.

Different combinations of parental crosses indicated that silencing of ATP synthase $\beta$ affected the egg maturation process and severely hampered offspring production of $E$. variegatus. Studies on Drosophila melanogaster indicated that ATP synthase subunits are required for germ cell maturation both in males (Chen et al. 2015; Yu et al. 2019) and females (Teixeira et al. 2015). Knockdown of ATP synthase b subunit induces male sterility with disruption of nuclear bundles during spermatogenesis and abnormal shaping during spermatid elongation leading to the absence of mature sperm in the seminal vesicle of male testes (Chen et al. 2015). Moreover, knockdown of ATP synthase $\beta$ subunit in germ cells results 
in male infertility and lack of germ cell maturation, probably due to an alteration of germ cell maintenance in Drosophila testes rather than defects in germ cell differentiation, indicating a critical role for this enzymatic complex in spermatogenesis (Yu et al. 2019). On the other hand in ovaries, ATP synthase promotes the maturation of mitochondrial cristae during germ line differentiation through dimerization and specific up-regulation of the ATP synthase complex, independently from ATP synthesizing function (Teixeira et al. 2015). Juvenile hormone (JH) plays a major role in insect development and reproductive process ( $\mathrm{Li}$ et al. 2019), and in particular, in lipid metabolism, which is crucial for correct egg formation (Wyatt and Davey 1996). About 40\% of the dry weight of Manduca sexta eggs is made of lipids (vitellogenins and lipophorins), and most of these lipids are transported from the fat body to the ovary by lipoproteins (Kawooya and Law 1988). In the greater wax moth (Galleria mellonella), the ectopically expressed ATP synthase $\alpha$ and $\beta$ subunits located on the plasma membrane of the insect fat body take part in exporting the haemolymph juvenile hormone-binding protein (JHBP) from the fat body, where it is synthetized, to the hemolymph (Zalewska et al. 2009). The JHBP protein acts as carrier of the JH through a multi-molecular structure involving several interacting storage proteins (apolipophorin, arylphorin and hexamerin) to enable hormone transport to target tissues (Zalewska et al. 2009). Moreover, the ectopic $\beta$ subunit of ATP synthase acts as a docking lipophorin receptor at the ovary of the hematophagous insect Panstrongylus megistus (Fruttero et al. 2017). Lipophorin is the main lipid carrier in insect hemolymph, and during vitellogenesis it delivers its hydrophobic units to developing oocytes by binding ATP synthase $\beta$ and probably other receptors at the plasma membrane of the cells (Fruttero et al. 2017). Indeed, the involvement of ATP synthase $\beta$ in lipid metabolism is probably an ancestral role, as this protein acts as a receptor also in mammalian hepatic HDL-cholesterol uptake (Vantourout et al. 2010). We can speculate that silencing of ATP synthase $\beta$ of $E$. variegatus could impair the trafficking pathway of $\mathrm{JH}$ and reduce lipid transport to developing oocytes, resulting in the absence of offspring. The absence of mature eggs in the ovaries of ATP synthase-silenced E. variegatus females was associated with hexamerin upregulation. Hexamerins are high molecular mass molecules composed of six subunits and mainly have a role as storage proteins (Martins et al. 2011). They are a source of amino acids and supply resources for metabolic processes, such as moulting or egg formation in females (Hathaway et al. 2009). The levels of these hemolymph storage proteins vary within life stages and are affected by diet (Hathaway et al. 2009; Hatle et al. 2001). Moreover, negative correlation between levels of hexamerins and vitellogenin has been observed in the cecropia moth Hyalophora cecropia, in the monarch butterfly Danaus plexippus (Pan and Telfer 2001) and the autogenous mosquito Aedes atropalpus (Wheeler and Buck 1996). Depletion of hexamerins may supply amino acids necessary for vitellogenin accumulation during oocyte development. The regular development of eggs and the abundance of a $200 \mathrm{kDa}$ protein (presumably vitellogenin, although in the absence of specific protein identification) observed in dsGFP-injected E. variegatus females compared to dsATP samples, suggest a negative correlation between the two proteins in silenced insects. The expression of vitellogenin mRNAs in ovaries did not vary among dsGFP- and dsATP-injected E. variegatus at 15 dpi, suggesting that an altered regulation of vitellogenin may occur at post-trascriptional level or before $15 \mathrm{dpi}$.

Beside hexamerin and vitellogenin, the transcript level of three $E$. variegatus genes, namely cathepsin L, perilipin and digestive cysteine protein, known to be involved in oocytes development (Telang et al. 2013), was investigated in dsGFPand dsATP-injected insects. Cathepsin L showed a trend of over-expression in whole body samples of dsATP-injected females and was over-expressed in ovaries of silenced females both at transcript and protein level. Cathepsins are proteases generally stored in lysosomes and are involved in several processes such as development, apoptosis, and immunity of arthropods (Saikhedkar et al. 2015; Waniek et al. 2012). Several isoforms of cathepsin $L$ are expressed in E. variegatus (Galetto et al. 2018), and the primer pair used here specifically targeted the isoform 473 , which is more transcribed in females than in males (Galetto et al. 2018), and therefore more likely to be involved in oocyte development. Also, the immunogenic peptide recognized in Western blot by the commercial anti-cathepsin L antibody is more similar to isoform 473 than to the other isoforms (Galetto et al. 2018). Interestingly, cathepsin L is involved in oocyte development, ovulation and follicular atresia in mammals (Carnevali et al. 2006), and, in arthropods, is the major yolk cysteine proteinase stored as a quiescent proenzyme in eggs of the soft tick Ornithodoros moubata (Fagotto 1990), and the major vitellin proteolytic enzyme in yolk granules of the cockroach Blattella germanica (Nordin et al. 1991). Besides its role in egg yolk metabolism, cathepsin L is also involved in oocyte development of B. germanica (Irles et al. 2009), as well as of the oriental river prawn Macrobrachium nipponense (Zhao et al. 2013). These data support the hypothesis that high level of cathepsin L measured in ovaries of silenced E. variegatus females is related with the lack of mature eggs. The slight differences in cathepsin L protein migration observed between whole body and ovary samples, may be explained by differences in glycosylation, one of the post-translational processes occurring during cathepsin maturation (Katunuma 2010).

The main control strategies of phytoplasma diseases rely on insecticides to limit vector populations, with negative impact on non-target organisms and on public health. RNAi based-technologies are a promising approach for more specific and sustainable pest management strategies, provided identification of efficient insect gene targets. RNAi efficiency is variable among insect species (Zhu and Palli 
2020; Zotti et al. 2018), but it works efficiently in E. variegatus, where it is long-lasting and spreads to body districts far from the injection site (Abbà et al. 2019; Galetto et al. 2021). In conclusion, ATP synthase $\beta$ is a promising target gene, as its silencing increases insect mortality (Abbà et al. 2019), suppresses phytoplasma multiplication in the insect (Galetto et al. 2021) and, as demonstrated here, induces sterility of surviving insects. Although several strategies of dsRNAs delivery to sap-sucking insects have been recently explored (Liu et al. 2020; Mitter et al. 2017), the application of an efficient large-scale method still remains a tremendous challenge in crop protection.

Acknowledgments: The authors thank Dr. Francesca Degola for helping in 2D protein electrophoresis, Dr. Sabrina Palmano and Dr. Giulia Molinatto for assisting in microinjection procedure, Elena Zocca for providing plants for insect rearing, and Flavio Veratti for maintenance of insect colonies.

This research was supported by Fondazione Cassa di Risparmio di Torino, Projects Siglofit $(\mathrm{RF}=2016-0577)$ and FOotSTEP $(\mathrm{RF}=$ 2018-0678).

\section{References}

Abbà, S., Galetto, L., Ripamonti, M., Rossi, M., \& Marzachì, C. (2019). RNA interference of muscle actin and ATP synthase beta increases mortality of the phytoplasma vector Euscelidius variegatus. Pest Management Science, 75(5), 1425-1434. https://doi. org/10.1002/ps.5263

Albanese, P., Melero, R., Engel, B. D., Grinzato, A., Berto, P., Manfredi, M., ... Pagliano, C. (2017). Pea PSII-LHCII supercomplexes form pairs by making connections across the stromal gap. Scientific Reports, 7(1), 10067. https://doi.org/10.1038/ s41598-017-10700-8

Arricau-Bouvery, N., Duret, S., Dubrana, M.-P., Batailler, B., Desqué, D., Béven, L., ... Foissac, X. (2018). Variable membrane protein A of flavescence dorée phytoplasma binds the midgut perimicrovillar membrane of Euscelidius variegatus and promotes adhesion to its epithelial cells. Applied and Environmental Microbiology, 84(8), 8-17. https://doi.org/ 10.1128/AEM.02487-17

Candiano, G., Bruschi, M., Musante, L., Santucci, L., Ghiggeri, G. M., Carnemolla, B., ... Righetti, P. G. (2004). Blue silver: A very sensitive colloidal Coomassie G-250 staining for proteome analysis. Electrophoresis, 25(9), 1327-1333. https://doi.org/ 10.1002/elps.200305844

Carnevali, O., Cionna, C., Tosti, L., Lubzens, E., \& Maradonna, F. (2006). Role of cathepsins in ovarian follicle growth and maturation. General and Comparative Endocrinology, 146(3), 195203. https://doi.org/10.1016/j.ygcen.2005.12.007

Caudwell, A., Kuszala, C., Larrue, J., \& Bachelier, J. (1972). Transmission de la Flavescence dorée de la fève à la fève par des cicadelles des genres Euscelis et Euscelidius. Annual Phytopathology, 181-189.

Chen, Y.-N., Wu, C.-H., Zheng, Y., Li, J.-J., Wang, J.-L., \& Wang, Y.-F. (2015). Knockdown of ATPsyn-b caused larval growth defect and male infertility in Drosophila. Archives of Insect Biochemistry and Physiology, 88(2), 144-154. https://doi.org/ 10.1002/arch.21209

Christiaens, O., Whyard, S., Vélez, A. M., \& Smagghe, G. (2020). Double-stranded RNA technology to control insect pests: Current status and challenges. Frontiers in Plant Science, 11, 451. https://doi.org/10.3389/fpls.2020.00451

Conti, M., D’Agostino, G., Casetta, A., \& Mela, L. (1988). Some characteristics of chrysanthemum yellows disease. Acta Horticulturae, (234): 129-136. https://doi.org/10.17660/ ActaHortic.1988.234.15

EFSA Panel on Plant Health. (2014). Scientific opinion on pest categorisation of grapevine Flavescence dorée. EFSA Journal, 12(10), 3851. https://doi.org/10.2903/j.efsa.2014.3851

Fagotto, F. (1990). Yolk degradation in tick eggs: I. Occurrence of a cathepsin L-like acid proteinase in yolk spheres. Archives of Insect Biochemistry and Physiology, 14(4), 217-235. https:// doi.org/10.1002/arch.940140403

Fongsaran, C., Jirakanwisal, K., Kuadkitkan, A., Wikan, N., Wintachai, P., Thepparit, C., ... Smith, D. R. (2014). Involvement of ATP synthase $\beta$ subunit in chikungunya virus entry into insect cells. Archives of Virology, 159(12), 3353-3364. https://doi. org/10.1007/s00705-014-2210-4

Fruttero, L. L., Leyria, J., Ramos, F. O., Stariolo, R., Settembrini, B. P., \& Canavoso, L. E. (2017). The process of lipid storage in insect oocytes: the involvement of $\beta$-chain of ATP synthase in lipophorin-mediated lipid transfer in the chagas' disease vector Panstrongylus megistus (Hemiptera: Reduviidae). Journal of Insect Physiology, 96, 82-92. https://doi.org/10.1016/j. jinsphys.2016.10.014

Galetto, L., Abbà, S., Rossi, M., Ripamonti, M., Palmano, S., Bosco, D., \& Marzachì, C. (2021). Silencing of ATP synthase $\beta$ reduces phytoplasma multiplication in a leafhopper vector. Journal of Insect Physiology, 128, 104176. https://doi.org/ 10.1016/j.jinsphys.2020.104176

Galetto, L., Abbà, S., Rossi, M., Vallino, M., Pesando, M. ArricauBouvery, N. ... Marzachì, C. (2018). Two phytoplasmas elicit different responses in the insect vector Euscelidius variegatus Kirschbaum. Infection and Immunity 86, e00042-18. https://doi. org/10.1128/IAI.00042-18

Galetto, L., Bosco, D., Balestrini, R., Genre, A., Fletcher, J., \& Marzachì, C. (2011). The major antigenic membrane protein of 'Candidatus Phytoplasma asteris' selectively interacts with ATP synthase and actin of leafhopper vectors. PLoS One, 6(7), e22571. https://doi.org/10.1371/journal.pone.0022571

Galetto, L., Bosco, D., \& Marzachì, C. (2013). Selection of reference genes from two leafhopper species challenged by phytoplasma infection, for gene expression studies by RT-qPCR. BMC Research Notes, 6(1), 409. https://doi.org/10.1186/ 1756-0500-6-409

Hathaway, M., Hatle, J., Li, S., Ding, X., Barry, T., Hong, F., ... Borst, D. (2009). Characterization of hexamerin proteins and their mRNAs in the adult lubber grasshopper: The effects of nutrition and juvenile hormone on their levels. Comparative Biochemistry and Physiology. Part A, Molecular \& Integrative Physiology, 154(3), 323-332. https://doi.org/10.1016/j.cbpa. 2009.06.018

Hatle, J. D., Borst, D. W., Eskew, M. R., \& Juliano, S. A. (2001). Maximum titers of vitellogenin and total hemolymph protein occur during the canalized phase of grasshopper egg production. 
Physiological and Biochemical Zoology, 74(6), 885-893. https://doi.org/10.1086/324475

Irles, P., Bellés, X., \& Piulachs, M. D. (2009). Identifying genes related to choriogenesis in insect panoistic ovaries by Suppression Subtractive Hybridization. BMC Genomics, 10(1), 206. https://doi.org/10.1186/1471-2164-10-206

Jeger, M., Bragard, C., Caffier, D., Candresse, T., Chatzivassiliou, E., Dehnen-Schmutz, K., ... the EFSA Panel on Plant Health. (2016). Risk to plant health of Flavescence dorée for the EU territory. EFSA Journal, 14(12), 4603. https://doi.org/10.2903/j. efsa.2016.4603

Kanakala, S., \& Ghanim, M. (2016). RNA interference in insect vectors for plant viruses. Viruses, 8(12), 329. https://doi. org/10.3390/v8120329

Katunuma, N. (2010). Posttranslational processing and modification of cathepsins and cystatins. Journal of Signal Transduction, 2010, 1-8. https://doi.org/10.1155/2010/375345

Kawooya, J. K., \& Law, J. H. (1988). Role of lipophorin in lipid transport to the insect egg. The Journal of Biological Chemistry, 263(18), 8748-8753. https://doi.org/10.1016/S0021-9258(18) 68369-3

Leyva, J. A., Bianchet, M. A., \& Amzel, L. M. (2003). Understanding ATP synthesis: Structure and mechanism of the F1-ATPase. Molecular Membrane Biology, 20(1), 27-33. https://doi. org/10.1080/0968768031000066532

Li, K., Jia, Q., \& Li, S. (2019). Juvenile hormone signaling - a mini review. Insect Science, 26(4), 600-606. https://doi.org/10.1111/ 1744-7917.12614

Liang, G.-F., Liang, Y., Xue, Q., Lu, J.-F., Cheng, J.-J., \& Huang, J. (2015b). Astakine LvAST binds to the $\beta$ subunit of F1-ATP synthase and likely plays a role in white shrimp Litopeneaus vannamei defense against white spot syndrome virus. Fish \& Shellfish Immunology, 43(1), 75-81. https://doi.org/10.1016/j. fsi.2014.12.015

Liang, Y., Cheng, J.-J., Yang, B., \& Huang, J. (2010). The role of F1 ATP synthase beta subunit in WSSV infection in the shrimp, Litopenaeus vannamei. Virology Journal, 7(1), 144. https://doi. org/10.1186/1743-422X-7-144

Liang, Y., Xu, M.-L., Wang, X.-W., Gao, X.-X., Cheng, J.-J., Li, C., \& Huang, J. (2015a). ATP synthesis is active on the cell surface of the shrimp Litopenaeus vannamei and is suppressed by WSSV infection. Virology Journal, 12(1), 49. https://doi. org/10.1186/s12985-015-0275-7

Lin, X., Kim, Y.-A., Lee, B. L., Söderhäll, K., \& Söderhäll, I. (2009). Identification and properties of a receptor for the invertebrate cytokine astakine, involved in hematopoiesis. Experimental Cell Research, 315(7), 1171-1180. https://doi. org/10.1016/j.yexcr.2009.01.001

Liu, S., Jaouannet, M., Dempsey, D. A., Imani, J., Coustau, C., \& Kogel, K.-H. (2020). RNA-based technologies for insect control in plant production. Biotechnology Advances, 39, 107463. https://doi.org/10.1016/j.biotechadv.2019.107463

Malembic-Maher, S., Desqué, D., Khalil, D., Salar, P., Bergey, B., Danet, J.-L., ... Foissac, X. (2020). When a Palearctic bacterium meets a Nearctic insect vector: Genetic and ecological insights into the emergence of the grapevine Flavescence doree epidemics in Europe. PLoS Pathogens, 16(3), e1007967. https://doi. org/10.1371/journal.ppat.1007967

Marcone, C. (2014). Molecular biology and pathogenicity of phytoplasmas. Annals of Applied Biology, 165(2), 199-221. https:// doi.org/10.1111/aab.12151
Margaria, P., \& Palmano, S. (2011). Response of the Vitis vinifera L. cv. 'Nebbiolo' proteome to Flavescence dorée phytoplasma infection. Proteomics, 11(2), 212-224. https://doi.org/10.1002/ pmic.201000409

Martins, J. R., Anhezini, L., Dallacqua, R. P., Simões, Z. L. P., \& Bitondi, M. M. G. (2011). A honey bee hexamerin, HEX 70a, is likely to play an intranuclear role in developing and mature ovarioles and testioles. PLoS One, 6(12), e29006. https://doi. org/10.1371/journal.pone.0029006

Mitter, N., Worrall, E. A., Robinson, K. E., Li, P., Jain, R. G., Taochy, C., ... Xu, Z. P. (2017). Clay nanosheets for topical delivery of RNAi for sustained protection against plant viruses. Nature Plants, 3(2), 16207. https://doi.org/10.1038/nplants. 2016.207

Nordin, J. H., Beaudoin, E. L., \& Liu, X. (1991). Acidification of yolk granules in Blattella germanica eggs coincident with proteolytic processing of vitellin. Archives of Insect Biochemistry and Physiology, 18(3), 177-192. https://doi.org/10.1002/arch. 940180306

Pan, M. L., \& Telfer, W. H. (2001). Storage hexamer utilization in two lepidopterans: Differences correlated with the timing of egg formation. Journal of Insect Science, 1(2), 1-8. https://doi. org/10.1673/031.001.0201

Rashidi, M., Galetto, L., Bosco, D., Bulgarelli, A., Vallino, M., Veratti, F., \& Marzachì, C. (2015). Role of the major antigenic membrane protein in phytoplasma transmission by two insect vector species. BMC Microbiology, 15(1), 193. https://doi. org/10.1186/s12866-015-0522-5

Ripamonti, M. (2019). Protein extraction from entire body-insects vl(protocols.io.w66fhe) https://doi.org/10.17504/protocols. io.w66fhhe

Saikhedkar, N., Summanwar, A., Joshi, R., \& Giri, A. (2015). Cathepsins of lepidopteran insects: Aspects and prospects. Insect Biochemistry and Molecular Biology, 64, 51-59. https:// doi.org/10.1016/j.ibmb.2015.07.005

Suzuki, S., Oshima, K., Kakizawa, S., Arashida, R., Jung, H.-Y., Yamaji, Y., ... Namba, S. (2006). Interaction between the membrane protein of a pathogen and insect microfilament complex determines insect-vector specificity. Proceedings of the National Academy of Sciences of the United States of America, 103(11), 4252-4257. https://doi.org/10.1073/pnas.0508668103

Taning, C. N., Arpaia, S., Christiaens, O., Dietz-Pfeilstetter, A., Jones, H., Mezzetti, B., ... Smagghe, G. (2020). RNA-based biocontrol compounds: Current status and perspectives to reach the market. Pest Management Science, 76(3), 841-845. https:// doi.org/10.1002/ps.5686

Taurino, F., \& Gnoni, A. (2018). Systematic review of plasmamembrane ecto-ATP synthase: A new player in health and disease. Experimental and Molecular Pathology, 104(1), 59-70. https://doi.org/10.1016/j.yexmp.2017.12.006

Teixeira, F. K., Sanchez, C. G., Hurd, T. R., Seifert, J. R. K., Czech, B., Preall, J. B., ... Lehmann, R. (2015). ATP synthase promotes germ cell differentiation independent of oxidative phosphorylation. Nature Cell Biology, 17(5), 689-696. https://doi.org/ $10.1038 / \mathrm{ncb} 3165$

Telang, A., Rechel, J. A., Brandt, J. R., \& Donnell, D. M. (2013). Analysis of ovary-specific genes in relation to egg maturation and female nutritional condition in the mosquitoes Georgecraigius atropalpus and Aedes aegypti (Diptera: Culicidae). Journal of Insect Physiology, 59(3), 283-294. https://doi.org/10.1016/j.jinsphys.2012.11.006 
Tomkins, M., Kliot, A., Marée, A. F., \& Hogenhout, S. A. (2018). A multi-layered mechanistic modelling approach to understand how effector genes extend beyond phytoplasma to modulate plant hosts, insect vectors and the environment. Current Opinion in Plant Biology, 44, 39-48. https://doi.org/10.1016/j.pbi. 2018.02.002

Trivellone, R., Ripamonti, M., Angelini, E., Filippin, L., Rossi, M., Marzachí, C., \& Galetto, L. (2019). Evidence suggesting interactions between immunodominant membrane protein Imp of Flavescence dorée phytoplasma and protein extracts from distantly related insect species. Journal of Applied Microbiology, 127(6), 1801-1813. https://doi.org/10.1111/jam.14445

Vantourout, P., Radojkovic, C., Lichtenstein, L., Pons, V., Champagne, E., \& Martinez, L. O. (2010). Ecto-F 1 -ATPase: A moonlighting protein complex and an unexpected apoA-I receptor. World Journal of Gastroenterology, 16(47), 5925-5935. https://doi.org/10.3748/wjg.v16.i47.5925

Waniek, P. J., Pacheco Costa, J. E., Jansen, A. M., Costa, J., \& Araújo, C. A. C. (2012). Cathepsin L of Triatoma brasiliensis (Reduviidae, Triatominae): Sequence characterization, expression pattern and zymography. Journal of Insect Physiology, 58(1), 178-187. https://doi.org/10.1016/j.jinsphys.2011.11.008

Weintraub, P. G., \& Beanland, L. (2006). Insect vectors of phytoplasmas. Annual Review of Entomology, 51(1), 91-111. https:// doi.org/10.1146/annurev.ento.51.110104.151039

Wheeler, D. E., \& Buck, N. A. (1996). A role for storage proteins in autogenous reproduction in Aedes atropalpus. Journal of Insect Physiology, 42(10), 961-966. https://doi.org/10.1016/00221910(96)00049-2

Wyatt, G. R., \& Davey, K. G. (1996). Cellular and molecular actions of juvenile hormone. II. Roles of juvenile hormone in adult insects. In Advances in Insect Physiology (Vol. 26, p. 1-155). Elsevier. https://doi.org/10.1016/S0065-2806(08)60030-2
Yu, J., Chen, B., Zheng, B., Qiao, C., Chen, X., Yan, Y., ... Fang, J. (2019). ATP synthase is required for male fertility and germ cell maturation in Drosophila testes. Molecular Medicine Reports, 19, 1561-1570. https://doi.org/10.3892/mmr.2019.9834

Zalewska, M., Kochman, A., Estève, J.-P., Lopez, F., Chaoui, K., Susini, C., ... Kochman, M. (2009). Juvenile hormone binding protein traffic - Interaction with ATP synthase and lipid transfer proteins. Biochimica et Biophysica Acta (BBA) - . Biomembranes, 1788(9), 1695-1705. https://doi.org/10.1016/j.bbamem.2009. 04.022

Zhao, W., Chen, L., Zhang, F., Wu, P., Li, E., \& Qin, J. (2013). Molecular characterization of cathepsin L cDNA and its expression during oogenesis and embryogenesis in the oriental river prawn Macrobrachium nipponense (Palaemonidae). Genetics and Molecular Research, 12(4), 5215-5225. https://doi. org/10.4238/2013.October.30.6

Zhu, K. Y., \& Palli, S. R. (2020). Mechanisms, applications, and challenges of insect RNA interference. Annual Review of Entomology, 65(1), 293-311. https://doi.org/10.1146/annurevento-011019-025224

Ziegler, R., \& Antwerpen, R. (2006). Lipid uptake by insect oocytes. Insect Biochemistry and Molecular Biology, 36(4), 264-272. https://doi.org/10.1016/j.ibmb.2006.01.014

Zotti, M., dos Santos, E. A., Cagliari, D., Christiaens, O., Taning, C. N. T., \& Smagghe, G. (2018). RNA interference technology in crop protection against arthropod pests, pathogens and nematodes. Pest Management Science, 74(6), 1239-1250. https://doi. org/10.1002/ps.4813

Manuscript received: 22 December 2020

Revisions requested: 2 January 2021

Modified version received: 22 February 2021

Accepted: 13 April 2021 